\title{
Nanomole per Liter per Milligram per Kilogram per Day
}

National Cancer Institute

\section{Source}

National Cancer Institute. Nanomole per Liter per Milligram per Kilogram per Day. NCI Thesaurus. Code C119459.

A unit of concentration equal to nanomoles per liter, divided by milligrams per kilogram per day. 